УДК: [616.74-007.23-02:616-005.4:616-018.1"712.4"]:58.089

DOI.ORG/10.37647/0132-2486-2021-109-2-58-62

\title{
Damages of Neuromuscular System After Mechanical-Induced Limb Ischemia (Experimental Study)
}

\author{
Pidlisetskyi A.T. ${ }^{1}$ 四
}

\begin{abstract}
Summary. Relevance. Traumatic and ischemic injury of the limbs is accompanied by damage of the skeletal muscles and peripheral nerves of the limbs. The dynamics and consequences of ischemic lesions remain poorly understood and need to be corrected. Objective: using quantitative morphological and sonographic methods, to study the dynamics of skeletal muscle damage of the limb after traumatically induced ischemia with and without the injection of platelet-rich plasma, bone marrow aspirate, and adipose tissue fraction. Materials and Metbods. In 3 experiments, rabbits were modeled with 6-bour limb ischemia by applying an elastic tourniquet. After compartment syndrome detection, based on the assessment of subfascial pressure, cell suspensions were injected into the leg muscles. Sonographic and histological examination of the muscles was performed on days 5, 15, and 30. The results of sonography and morphometry were evaluated by statistical methods. Results. The developed model of ischemia consists of 6-hour immobilization of the limb, on mwhich medical elastic tourniquets were imposing. The action of the tourniquets causes high subfascial pressure and necrosis of the superficial muscle groups of the lower third of the thigh and lower leg. According to sonography, the $\delta$-entropy of damaged tissues on day 5 is reduced relative to the intact limb, as in the case of administration of bone marrow aspirate cells. On days 15 and 30, sonography showed no difference between the comparison groups. The dynamics of morphological features of limb tissue damage consist of necrosis of superficial muscle groups, atrophy in the middle layers, and almost intact deep muscle groups. Necrosis was replaced by scar tissue, the density of which increases 11-14 times, and does not differ in the period 5-30 days. The administration of platelet plasma, bone marrow aspirate, and adipose tissue fraction did not change the dynamics of fibrotic changes in ischemic damaged muscles. Muscle atrophy is accompanied by activation of endogenous repair of single muscle fibers, which tended to intensify after injection of bone marrow aspirate. The sciatic nerve of the injured limb was not structurally damaged according to the deep topography, while the nerves of the tibia develop degenerative changes from the 15 th day.
\end{abstract}

Key words: ischemia; injury; skeletal muscles; cell therapy.

\section{Introduction}

Skeletal muscle and peripheral nerve damage after compression injury of the limb is a common complication. Long-lasting compression results in direct trauma and necrosis of muscle tissue, followed by ischemic reperfusion injury. The mechanisms underlying ischemia-reperfusion are complex and distinguish two types of interdependent changes structural and metabolic. Acute circulatory hypoxia of limb tissues remains less studied than structural changes, which are more isolated and understandable.

凶Pidlisetskyi A.T., apidlis@gmail.com

'SI "Institute of Traumatology and Orthopedics of NAMS of Ukraine", Kyiv
Muscle damage occurs not only as a result of direct injury to the limb but can occur as a consequence of compartment syndrome or on the background of limb`s blood vessels disorders [2]. Irreversible changes in the skeletal muscles of the extremities begin after 2 hours of ischemia, and after 4 hours, necrosis can reach $40 \%$ of muscle tissue [3]. Restoration of blood flow during reperfusion causes secondary tissue damage, as the accumulated cytotoxic metabolites penetrate the tissues, including through structurally damaged vessels of the limb [4]. As a result, edema, biochemical changes, and tissue necrosis progress.

It has been suggested that it is possible to correct the condition of ischemic injured limb muscles by injecting platelet plasma, bone marrow aspirate cells, 
or adipose tissue. Research results indicate the potential impact of these suspensions in delaying muscle damage and dystrophy after trauma or ischemia $[5,6,7,8,9]$. Therefore, studying the effects of cell technologies on ischemic muscles is relevant.

\section{Materials and Methods}

The developed experimental model consists of a reproduction of the combined mechanical and ischemic damage of an extremity's tissues reached by imposing on a hind leg of a rabbit Chinchilla (weighing $4,2-4$, and $5 \mathrm{~kg}$ ) a medical elastic plait. The number of tourniquets is 8 per limb, from the middle third of the thigh to the ankle joint. It achieved sufficient pressure and mechanical trauma to the extremity. The duration of limb immobilization was 6 hours. During this time, severe mechanical damage to the superficial skeletal muscle group occurs in the limb. When measuring subfascial pressure using a device "Stryker Intra-Compartmental Pressure Monitor" (USA), it was confirmed an increase in pressure over $30 \mathrm{mmHg}$, which was evaluated as a compartment syndrome in the bone-fascial sheaths of the lower leg. After confirmation of the syndrome, autologous platelet plasma, bone marrow aspirate, or SVF was injected into the injured leg. The protocol of receipt, preparation, and injection are described in detail in the article [10].

On days 5, 15, and 30, after removal of the tourniquets, changes in skeletal muscle and sciatic nerve in the injured limbs were histologically examined. The materials were fixed in $10 \%$ formalin solution, sealed in paraffin (Leica Surgipath Paraplast Regular, Formula 'R', Germany) through isopropanolchloroform. Micropreparations $6 \mu \mathrm{m}$ thick, stained with hematoxylin and eosin, were examined under a microscope Olympus BX 51 (Japan).

Directly, before animals were removed from the experiment, an ultrasound examination was performed to detect and assess the volume of necrotized tissue in the limb. To do this, ultrasound recognized $\delta$-entropy in areas of ischemic tissue and muscle in the contralateral limb. In a separate series of experiments, animals were injected with plateletrich plasma, bone marrow aspirate, or stromal vascular adipose tissue after knowledge of the elastic tourniquet. All manipulations on the animals were carried out by the provisions of bioethics and a meeting of the bioethics commission of the SI "Institute of Orthopedics and Traumatology of NAMS of Ukraine"; sodium thiopental was used at a dose of $60 \mathrm{mg} / \mathrm{kg}$. All statistical calculations were performed using the nonparametric Kruskal-Wallis test and oneway analysis of variance ANOVA. The differences were considered significant at $\mathrm{p}<0.05$.

\section{Results and Conclusions}

According to the results of sonographic studies, a decrease in entropy and after injection of a suspension of bone marrow aspirate concentrate was revealed only on the 5th day (Fig. 1). On days 15 and 30, the entropy level did not differ from the contralateral limb. Because necrosis of muscle tissue has been detected in recent experiments, it has been concluded that ultrasound has value in assessing changes in ischemic damaged limb tissue only in the early stages of injury.

Macroscopic examination revealed significant damage to the muscles of the calf group: edema with a large amount of exudate (up to $2.0 \mathrm{ml}$ ), the acute blood supply to blood vessels and hemorrhages, and reduced density and loss of muscle tissue color (from pink to yellow-white) (Fig. 2). Such characteristic damage to the leg muscles was observed on days 5 and 15. On day 30, free exudate was almost absent, but areas of hemorrhage and muscle necrosis were still recorded. After the introduction of platelet plasma or bone marrow aspirate, no visual differences were detected, while the injection of SVF caused encapsulation of adipose tissue and severe angiogenesis.

Analysis of microstructural changes in the leg muscles revealed the dynamics of skeletal muscle disorders. Initially, necrosis of muscle groups accompanied by edema, necrosis of blood vessels, and hemorrhagic infiltration of the muscle interstitium, then connective tissue replaced the area of necrosis and atrophy of muscle fibers with the formation of a scar. On the 15 th day, the density of fibrosis areas significantly increased. On the 30th day, it remained unchanged or tended to increase. Thus, if in the intact muscle the amount of connective tissue was $4.74 \pm 0.51 \%$, then after ischemia, it was $53.87 \pm 1.61 \%, 52.68 \pm 1.47 \%$, and $69.89 \pm 0.85 \%$. There were no differences between the groups with mechanical ischemia and groups injected with platelet-rich plasma, bone marrow aspirate concentrate, and SVF. Although on 30th day, the relative density of collagen sites was slightly lower in the first two groups, which requires further study and possibly is not associated with the direct introduction of these funds. An increase in the number of myocyte nuclei was recorded, which indicates the activation of regenerative processes in the muscle fiber in single damaged muscle fibers.

The topographic dependence of muscle's damage level was revealed. Necrosis occurred in the superficial groups of muscle fibers. Atrophy was revealed in the middle group of muscles, and deep ones remain almost undamaged. Structurally preserved sciatic and femoral nerves were found between the deep muscle groups. Their fascicular structure remained preserved throughout the experiment; distal branches of the peripheral shin nerves had been damaged and 

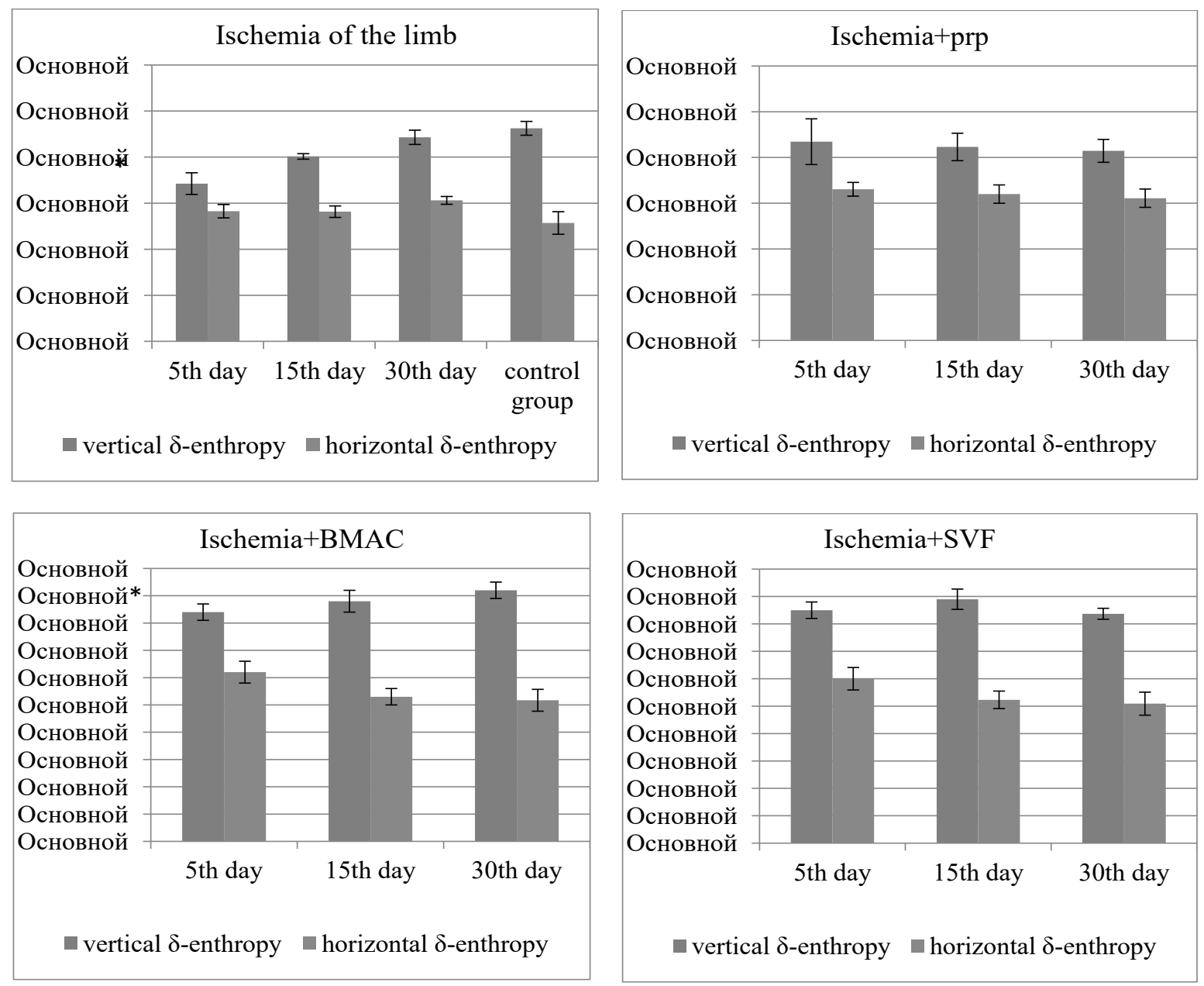

Fig. 1. The level of entropy in the muscles of the ischemic damaged limb Note: * reliable for control (contralateral limb)

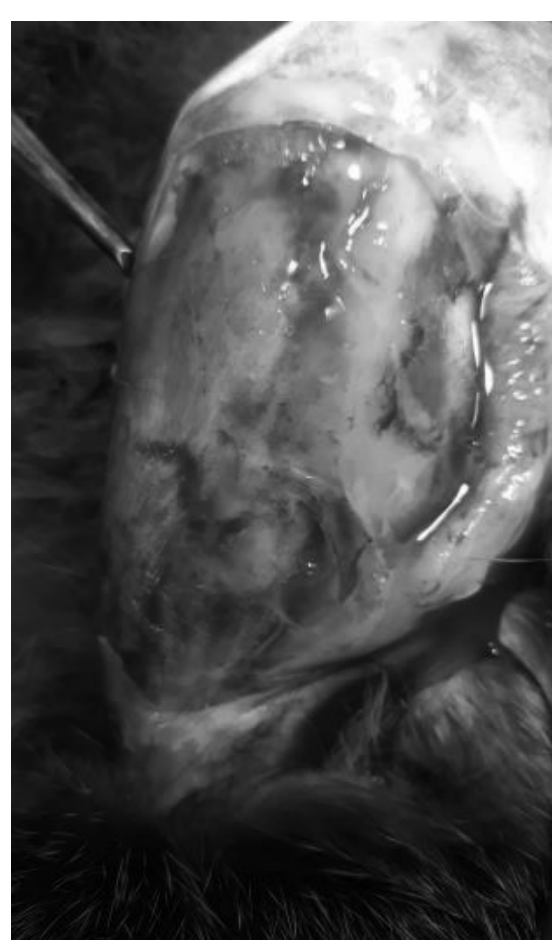

a)

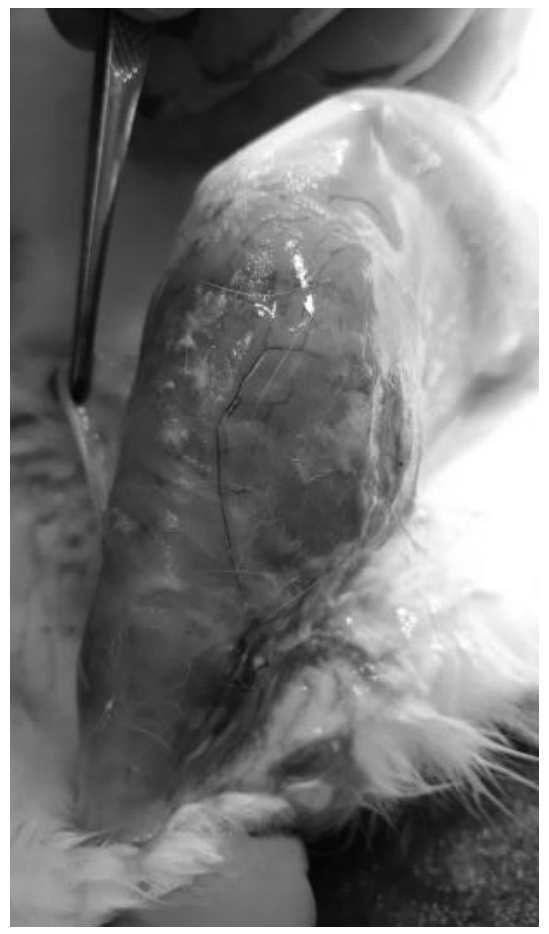

b)

Fig. 2. Damage to the limb on the 5 th (a) and 15 th days (b) after mechanically induced ischemia 
degenerative changes were found in them. There was no difference between the density of nerve fibers in the sciatic nerve of the injured limb and contralateral. Degeneration of myelinated nerve fibers was revealed in the fasciculus of the tibial nerve on the 15th and 30 th days after the onset of compartment syndrome. These changes were isolated, at the level of individual fascicles that did not affect changes in the density of nerve fibers in the sciatic nerve. It is important to note that on the 15th and 30th days in the areas of atrophy, there were signs of activation of regeneration of individual muscle fibers: the appearance of additional myocyte nuclei and the formation of longitudinal groups of satellite cells. This reaction was observed in almost all samples, but the intergroup comparison was more significant after the injection of bone marrow aspirate cells.

According to morphological data, we assume that 6-hour mechanically induced ischemia, which includes two factors (trauma and impaired perfusion in the vessels), causes primary necrosis of muscle tissue in the superficial group of limb muscles. Injuries of deep muscles are associated with ischemia and secondary tissue changes. The revealed changes in the peripheral nerves of the tibia are explained either by the action of the tourniquet or by metabolic changes. The reaction to the injection of adipose tissue was accompanied by activation of fibrosis processes, while the suspension of bone marrow aspirate concentrate did not cause changes (inflammation, osteogenesis, etc.), as well as platelet-rich plasma. We assume that bone marrow aspirate concentrate may promote activation of endogenous regenerative processes in damaged skeletal muscles. It is indicated by the results of biochemical studies [11]. Thus, after the injection of bone marrow aspirate concentrate into ischemic leg muscles, there was a significant increase in the activity of catalase and glutathione peroxidase enzymes for 15 and 30 days and, conversely, decreased $\mathrm{NO}^{2-}$. This indicates the activation of the antioxidant defense system and the neutralization of the cytotoxic metabolite $\mathrm{NO}^{2-}$. The effect of platelet plasma was less significant in terms of ischemic muscle damage, but also affected the reduction of oxidative modification of proteins. Given the multicomponent nature of bone marrow aspirate concentrate, SVF, and platelet-rich plasma, it is difficult to detect the specific effect of specific drugs. One can only speculatively assume the role of the cytokine system of the bone marrow $[8,12]$ in the composition of the autologous aspirate in reducing the inflammatory process, delaying malnutrition, and activation of regenerative processes in the muscle tissue of the ischemic damaged limb.

Conflict of interest. The authors declare no conflict of interest. This publication has not been, is not, and will not be the subject of commercial interest in any form.

\section{References}

1. Scimeca M, Bonanno E, Piccirilli E, Baldi J, Mauriello A, Orlandi A, Tancredi V, Gasbarra E, Tarantino U. Satellite Cells CD44 Positive Drive Muscle Regeneration in Osteoarthritis Patients. Stem Cells Int. 2015;2015:469459. DOI: $10.1155 / 2015 / 469459$

2. Kim JG, Lee J, Roe J, Tromberg BJ, Brenner M, Walters TJ. Hemodynamic changes in rat leg muscles during tourniquetinduced ischemia-reperfusion injury observed by nearinfrared spectroscopy. Physiol Meas. 2009;30(7): 529-540. DOI: 10.1088/0967-3334/30/7/001.

3. Tran TP, Tu H, Pipinos II, Muelleman RL, Albadawi H, Li YL. Tourniquet-induced acute ischemia-reperfusion injury in mouse skeletal muscles: Involvement of superoxide. Eur J Pharmacol. 2011;650(1): 328-334. DOI: 10.1016/j. ejphar.2010.10.037.

4. Ikebe K, Kato T, Yamaga M, Hirose J, Tsuchida T, Takagi K. Increased Ischemia-Reperfusion Blood Flow Impairs the Skeletal Muscle Contractile Function. J Surg Res. 2001; 99(1): 1-6. DOI: 10.1006/jsre.2001.6134.

5. Leroux L, Descamps B, Tojais NF, Séguy B, Oses P, Moreau C, Daret D, Ivanovic Z, Boiron JM, Lamazière JM, Dufourcq P, Couffinhal T, Duplàa C. Hypoxia preconditioned mesenchymal stem cells improve vascular and skeletal muscle fiber regeneration after ischemia through a Wnt4-dependent pathway. Mol Ther. 2010;18(8): 1545-1552. DOI: 10.1038/ mt.2010.108.

6. Ismail AM, Abdou SM, Aty HA, Kamhawy AH, Elhinedy M, Elwageh M, Taha A, Ezzat A, Salem HA, Youssif S, Salem ML. Autologous transplantation of CD34(+) bone marrow-derived mononuclear cells in management of non-reconstructable critical lower limb ischemia. Cytotechnology. 2016;68(4): 771-781. DOI: 10.1007/s10616-014-9828-7.

7. Liew A, O'Brien T. Therapeutic potential for mesenchymal stem cell transplantation in critical limb ischemia. Stem Cell Res Ther. 2012;3(4):28.

8. Torres-Torrillas M, Rubio M, Damia E, Cuervo B, Del Romero A, Peláez P, Chicharro D, Miguel L, Sopena JJ. Adipose-Derived Mesenchymal Stem Cells: A Promising Tool in the Treatment of Musculoskeletal Diseases. Int J Mol Sci. 2019;20(12):3105. DOI: $10.3390 /$ ijms20123105.

9. Lalegül-Ülker Ö, Şeker ş, Elçin AE, Elçin YM. Encapsulation of bone marrow-MSCs in PRP-derived fibrin microbeads and preliminary evaluation in a volumetric muscle loss injury rat model: modular muscle tissue engineering. Artif Cells Nanomed Biotechnol. 2019;47(1):10-21. DOI: 10.1080/21691401.2018.1540426.

10. Pidlisetskyy A, Savosko S, Dolhopolov O, Makarenko O. Peripheral nerve lesions after a mechanically induced limb ischemia. Georgian Med News. 2021;(310):165-169.

11. Pidlisetsky A.T., Kosiakova G.V., Goridko T.M., Berdyschev A.G., Meged O.F., Savosko S.I., Dolgopolov O.V. Administration of platelet-rich plasma or concentrated bone marrow aspirate after mechanically induced ischemia improves biochemical parameters in skeletal muscle. Ukr.Biochem.J. 2021;93(3):3038. DOI: https://doi.org/10.15407/ubj93.03.030.

12. Sassoli C, Vallone L, Tani A, Chellini F, Nosi D, ZecchiOrlandini S. Combined use of bone marrow-derived mesenchymal stromal cells (BM-MSCs) and platelet-rich plasma (PRP) stimulates proliferation and differentiation of myoblasts in vitro: new therapeutic perspectives for skeletal muscle repair/regeneration. Cell Tissue Res. 2018;372(3):549570. DOI: $10.1007 / \mathrm{s} 00441-018-2792-3$. 


\section{Пошкодження нервово-м'язового апарату при механічно індукова- ній ішемії кінцівки (експериментальна модель)}

Підлісещький А.T. ${ }^{1}$

'ДУ "Інститут травматологї та ортопедії НАМН України", м. Київ

Резюме. Актуальність. Травматичне та ішемічне пошкодження кінцівки супроводжується ураженням скелетних м'язів та периферійних нервів кінцівки. Динаміка і наслідки ішемічного ураження залишаються маловивченими і потребують корекиї. Мета дослідження. Кількісними морбологічними та сонографічними методами дослідити динаміку пошкодження скелетних м'язів кінцівки після травматично індукованої ішемії з та без введення збагаченої тромбоцитами плазми, аспірату кісткового мозку та фракиї жирової тканини. Матеріали i.методи. В 3 експериментальних серіях кролям моделювали 6-годинну травматично індуковану ішемію кінцівки, після виявлення компартмент-синдрому на основі оцінки підфасціального тиску, у м'язи гомілки вводили клітинні суспензії. На 5-ту, 15-ту і 30-ту добу проведено сонографічне та гістологічне дослідження м'язів пошкодженої кінцівки. Результати сонографії та морфометрії оцінено статистичними методами. Результати та висновки. Розроблена модель ішемії кінцівки полягає у 6-годинній іммобілізащії кінцівки, на яку накладено медичні еластичні джгути. Дія джгутів викликає високий підфасціальний тиск у кінцівці i некроз поверхневих груп м'язів нижнъої третини стегна $і$ гомілки. За даними сонограбії, $\delta$-ентропія пошкоджених тканин на 5-ту добу знижена щодо неушкодженої кінцівки, як і після введення клітин аспірату кісткового мозку. На 15-ту i 30-ту добу сонографбія не показала різниці між групами порівняння. Динаміка морфологічних особливостей пошкодження тканин кінщівки полягає у некрозі поверхневих груп м'язів, атрофіїу середніх шарах імайже не змінених глибоких груп м'язів. Некроз замішується рубцевою сполучною тканиною, щільність якої зростає у 11-14 разів і у термінах між 5-ю і 30-ю добою не відрізняється. Введення тромбоцитарної плазми, аспірату кісткового мозку та фракиї жирової тканини не вплинуло на зміну динаміки розвитку фіброзних змін у ішемічно пошкоджених м'язах. Атробія м'язів супроводжується активацією ендогенного відновлення поодиноких м'язових волокон, яка мала тенденцію до інтенсифікації після введення аспірату кісткового мозку. Сідничний нерв пошкодженої кінцівки не зазнав структурного пошкодження з огляду глибокої топографії, тоді яку нервах гомілки виникають дегенеративні зміни з 15-ї доби.

ключові слова: ішемія; травма; скелетні м'язи; клітинна терапія. 